\title{
ACADEMIC AND TECHNICAL VOCABULARIES OF MANAGEMENT STUDIES IN ABSTRACTS PUBLISHED IN REPUTABLE JOURNALS
}

\author{
Murniati* \\ English Language and Culture Department, Bunda Mulia University \\ Received on 4 August 2017 / Approved on 25 September 2017
}

\begin{abstract}
This research aims to find the academic vocabularies as well as the technical vocabularies in abstracts published in reputable journals. The topics of the abstracts are retail, marketing, human resource, finance, and strategic management. Those topics are chosen since those five topics are the streams in Bunda Mulia University under Management Departments. Moreover, there is a corpus based program named wordandphrase.info to analyze both academic and technical vocabularies in those five topics. The data is gained from abstracts published in reputable journals retrieved from www.sciencedirect.com. The results show that the percentage of the top 1-500 academic words used in abstract is from $20 \%$ to $30 \%$. Regarding the next 500 3.000 academic words list, the range of those words used is between $7 \%$ to $10 \%$. The range of the technical vocabularies is, however, different from one topic to another. The range of technical vocabularies in retail and marketing is about $5 \%$, while in finance, human resource and strategic management, the range is between 0.4 to $2 \%$.
\end{abstract}

Keywords: academic vocabularies, technical vocabularies, business

\section{ABSTRAK}

Penelitian ini bertujuan untuk menemukan kosa kata akademik serta kosa kata teknis dalam abstrak yang diterbitkan di jurnal terkemuka. Topik abstrak adalah ritel, pemasaran, sumber daya manusia, keuangan, dan manajemen strategis. Topik-topik tersebut dipilih karena kelima topik tersebut adalah bidang ilmu yang dipelajari di Universitas Bunda Mulia di bawah Departemen Manajemen. Selain itu, ada program berbasis corpus yaitu wordandphrase.info yang dapat digunakan untuk untuk menganalisis kosakata akademis dan teknis dalam kelima topik tersebut. Data yang digunakan di penelitian ini diperoleh dari abstrak yang diterbitkan di jurnal terkemuka yang diambil dari www.sciencedirect.com. Hasilnya menunjukkan bahwa persentase dari 5.000 kata akademik teratas yang digunakan secara abstrak adalah dari $20 \%$ sampai 30\%. Mengenai 500 - 3.000 daftar kata akademis berikutnya, kisaran kata-kata yang digunakan adalah antara 7\% sampai 10\%. Kisaran kosa kata teknis berbeda dari satu topik ke topik lainnya. Kisaran kosakata teknis dalam ritel dan pemasaran sekitar 5\%, sedangkan di bidang keuangan, manajemen sumber daya manusia dan strategis, kisarannya antara 0,4 sampai $2 \%$.

Kata Kunci: kosakata akademik, kosa kata teknis, bisnis

\section{INTRODUCTION}

\section{Background of Study}

English as a Global Language has become more popular due to the widely use of internet. It allows all people to communicate with other people around the world easily. The communication has later increased the "public recognition of the global position of English"
(Crystal, 2003). In relation to it, Kachru (1989) has divided the English language into three concentric circles. The first circle is called as the inner circle. The countries which belong to this circle are those which use English as the mother tongue, for example England and America. Next, some countries which serve English as the second language, in a multilanguage community are categorized as the

*Author(s) Correspondence:

E-mail: murniati@bundamulia.ac.id 
outer circle. Singapore and The Philippines belong to this circle. The rests, where English is studied at school as a foreign language, are grouped as the expanding circle. Indonesia and Iraq are the examples of countries from the expanded circle.

Crystal (2003) in his book also argues that English as a global language allows academic publication to increase in weight. One of them is research articles written by the university lecturers. In other words, it can be said that the research articles they have to write is also affected by the global language. The effects range from the topic which could be broader as well as the language itself. Regarding the language, it can be seen how differentthe language would be after English as the global language is widely recognized. For examples, the vocabularies produced by lecturers whose English is not the first language would be different from the ones produced by lecturers whose English is the mother tongue.

Regarding the English vocabulary in the academic texts, Nation (2001) mentions that there are four kinds of vocabularies found. The first category is the high frequency words. It means that the words are the common and general ones. The second is the academic words. It means that all academic texts mostly use the words found under this category. The next category is the technical vocabularies. It means that the words are found in a specific area of study. For example, the word "semantics" is found in the area of English language. The last category is the low frequency words. Those words are rarely used in academic texts since it is uncommon.

\section{Statement of Problem and Research Questions}

The background has indicated that little attention has been paid to the academic vocabularies, especially in academic texts. In addition, the abstract published in a reputable journal should follow certain rules regarding the English vocabularies used. This present research is therefore aims to answer the following research questions.

\footnotetext{
*Author(s) Correspondence:

E-mail: murniati@bundamulia.ac.id
}

1) What are the academic and technical vocabularies found in the abstracts of the researches published in the reputable journals?

2) To what extent are the technical vocabularies regarding retails, marketing, human resources, finance, and strategic management is different from one to another?

\section{Research Objectives}

The objective of this research is first, to determine the high frequency, academic, technical, and low frequency vocabularies in the abstracts of research regarding business published in reputable journals. Next, it would also like to see whether those high frequency, academic, technical, and low frequency vocabularies are produced differently from one stream to another.

\section{Research Significance}

Indonesian government has published several regulations regarding publishing journal articles in reputable journals. The ones recognized are usually published in English language; it is therefore the English language must really meet the expectations. First, it must cover the academic vocabulary. Second, the vocabulary should be related to the topic area. If the article is about business, then the Business vocabularies must be used. Writing down a research article by using general vocabularies may result to the unaccepted article to be published. It is expected that lecturers of Management Department in Bunda Mulia University can make use the results of this research as the reference of which business English vocabulary should be used while writing down the abstracts.

\section{THEORETICAL FRAMEWORK}

Corpus linguistics deals with how language is used in real-life contexts. The term "corpus" refers to the collection of words used in a natural usage of a language (Hunston, 2005). The fast growing technology allows people to create corpus software to analyze the language, especially English. 
People can see the frequency of words, differentiate between spoken and written language used, and the field where certain language is used by using that corpus software. Corpus linguistics can also be used for academic reasons, since people need to focus on which words should be used in academic contexts (Coxhead, 2000). Recognizing academic words used is also important for the sake of the readers. If the first 1-500 words are used more than $500-3000$ words found in the list, then the written texts can easily be understood (Martín-Monje, Elorza, \& Riaza, 2016).

Nation (2001) distinguishes four kinds of vocabulary found in a text. They are high frequency words, technical vocabulary, semi technical vocabularies, and low frequency vocabularies. The high frequency words are the words which commonly appear in an academic text. It usually covers $80 \%$ of the overall texts. Those words can be found in General Service List (GSL) of English Words composed by Michael West. Some content words, such as government, production, and represent belong to GSL.

Richards \& Schmidt (2013) defines technical vocabulary as "words specific to a particular topic, field, or discipline". Nation (2001) argues that the technical vocabulary covers $9 \%$ from the overall texts. Those words are specific to a field; it can be said that words in business texts may be different from words used in texts about education. For example, the word "teacher" is categorized as technical vocabulary in education.

Semi technical vocabularies, which usually cover $5 \%$ of the overall words in a text, are words which are academic but may appear in several areas. The examples of semi technical vocabularies are method, impact, and hypothesis. The low frequency vocabularies cover for about another $5 \%$ of the overall texts. Those words rarely appear in the common academic texts.

\section{RESEARCH METHOD}

\section{Source of Data}

The data is gained from the abstracts of research articles published in the reputable journals. Those abstracts are downloaded from www.sciencedirect.com. To maintain its reliability and validity, the abstracts are chosen from the ones published in 2016 to 2017. There are 15 journals chosen from 5 streams. The journals are chosen from the first thee highest journals published the more articles. From the Retail stream, the three journals are (1) Journal of Business Research, (2) Journal of Retailing and Consumer Services, and (3) European Journal of Operational Research. In Marketing areas, they are (1) Journal of Business Research, (2) Industrial Marketing Management, and (3) Procedia-Social and Behavioral Sciences. Regarding the Human Resource, the journals are (1) Procedia-Social and Behavioral Sciences, (2) Human Resource Management Review, and (3) European Management Journal. The topic of finance is covered by three journals: (1) Research in International Business and Finance, (2) Procedia Economics and Finance, and (3) Procedia-Social and Behavioral Sciences. The last three journals in Strategic Management areas are (1) Procedia-Social and Behavioral Sciences, (2) European Journal of Operational Research, and (3) Journal of Business Research.

\section{Data Collection Procedures}

The data is collected one by one, starting from searching each keyword in in www.sciencedirect.com. After that, the year is limited to 2016 and 2017. The first three journals which have the highest publications are chosen. The first ten newest articles are chosen. Finally, the abstracts are downloaded. They are all saved in word documents. In short, all of them can be seen in the figure below.

\footnotetext{
*Author(s) Correspondence:

E-mail: murniati@bundamulia.ac.id
} 
Figure 1. Data Collection Procedures

\begin{tabular}{|l|l|}
\hline 1 & $\begin{array}{l}\text { - Limiting the search in www.sciencedirect com by searching } \\
\text { each keyword in www.sciencedirect.com }\end{array}$ \\
\hline & - Limiting the year to 2016 to 2017 \\
\hline & - Choosing three journals for each category \\
\hline & - Choosing the first ten articles \\
\hline
\end{tabular}

\section{Data Analysis Procedures}

In order to answer research question number 1 , several steps are conducted. It can be seen in Figure 2. As can be seen, after all of the data is uploading, the high frequency, academic, technical, and low frequency words can be seen. It will be analyzed whether they are sufficient enough or not. After that, the analysis is limited to Business vocabularies.
When it is chosen, all business English found in the abstract can be seen. Later, there should be conclusion saying whether each particular abstract has met the qualifications of academic texts or not in terms of its vocabulary.

Meanwhile, in order to answer research question 2, several steps as can be seen in Figure 3 is conducted.

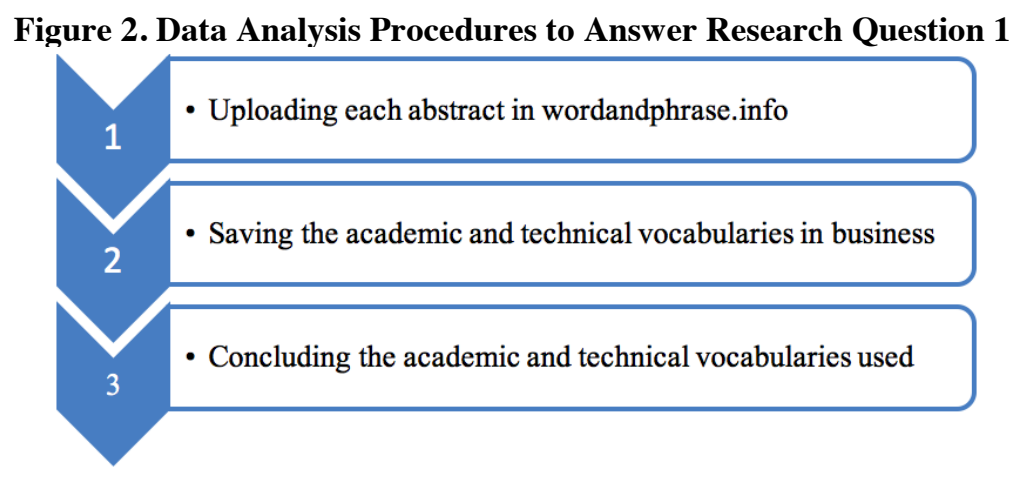

Figure 3. Data Analysis Procedures to Answer Research Question 2

1

- Grouping all of the academic (in business) vocabularies

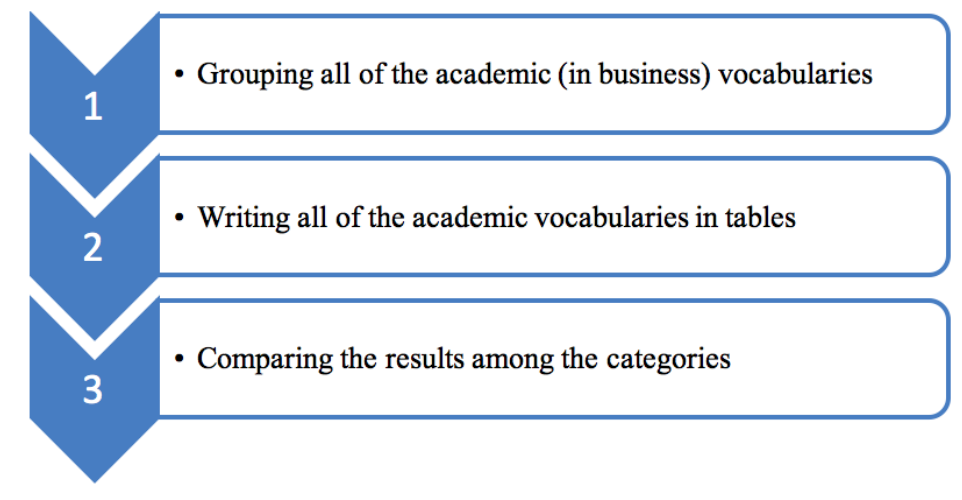

*Author(s) Correspondence:

E-mail: murniati@bundamulia.ac.id 


\section{RESULTS AND DISCUSSION}

The findings presented in this chapter are organized based on the vocabularies found in the abstracts. The number of words are presented in tables and found the average. In the same table, the technical and academic vocabularies are presented. The second table in each part discusses the business vocabularies as parts of technical vocabularies found in each topic, together with their occurrences. The results can also be used as the recommendation for lecturers who are going to write abstracts of research articles in business.

\section{Retail}

The first finding discussed in this chapter is regarding the retail. It is presented first since retail is the main characteristics in
Management Department in Universitas Bunda Mulia. The following findings regarding the usages of vocabulary in retail are taken from three reputable journals: (1) Journal of Business Research, (2) Journal of Retailing and Consumer Services, and (3) European Journal of Operational Research.

Table 1 below presents the total of words found in each abstracts. The next column shows the percentage of academic vocabularies which belong to the top 1-500 words. The fourth column shows the academic vocabularies which appear in the $501-3000$ lists of Academic Vocabularies list. The last column discusses the percentage of technical vocabularies - in this case, business - found in each abstract. The format of this table is also used in explaining the occurrences of both academic and technical vocabularies found in each abstract in each topic area.

Table 1. Percentage of Academic and Technical Vocabularies in Retail

\begin{tabular}{|c|c|c|c|c|}
\hline $\begin{array}{c}\text { Journals } \\
\text { (retail) }\end{array}$ & Words & $1-500$ & $501-3000$ & Business \\
\hline 1 & 130 & $18 \%$ & $11 \%$ & $5 \%$ \\
\hline 2 & 85 & $33 \%$ & $8 \%$ & $5 \%$ \\
\hline 3 & 149 & $19 \%$ & $8 \%$ & $5 \%$ \\
\hline 4 & 155 & $15 \%$ & $12 \%$ & $5 \%$ \\
\hline 5 & 101 & $35 \%$ & $9 \%$ & $2 \%$ \\
\hline 6 & 101 & $31 \%$ & $6 \%$ & $6 \%$ \\
\hline 7 & 94 & $31 \%$ & $6 \%$ & $4 \%$ \\
\hline 8 & 146 & $26 \%$ & $6 \%$ & $7 \%$ \\
\hline 9 & 96 & $26 \%$ & $11 \%$ & $5 \%$ \\
\hline 10 & 147 & $31 \%$ & $7 \%$ & $6 \%$ \\
\hline 11 & 100 & $21 \%$ & $8 \%$ & $9 \%$ \\
\hline 12 & 139 & $27 \%$ & $8 \%$ & $9 \%$ \\
\hline 13 & 97 & $24 \%$ & $5 \%$ & $6 \%$ \\
\hline 14 & 182 & $22 \%$ & $5 \%$ & $6 \%$ \\
\hline 15 & 181 & $24 \%$ & $18 \%$ & $4 \%$ \\
\hline 16 & 180 & $23 \%$ & $8 \%$ & $3 \%$ \\
\hline 17 & 110 & $34 \%$ & $5 \%$ & $6 \%$ \\
\hline 18 & 136 & $22 \%$ & $7 \%$ & $8 \%$ \\
\hline 19 & 120 & $30 \%$ & $7 \%$ & $2 \%$ \\
\hline 20 & 150 & $24 \%$ & $8 \%$ & $7 \%$ \\
\hline 21 & 230 & $21 \%$ & $13 \%$ & $6 \%$ \\
\hline 22 & 247 & $25 \%$ & $10 \%$ & $4 \%$ \\
\hline 23 & 131 & $18 \%$ & $5 \%$ & $2 \%$ \\
\hline 24 & 141 & $22 \%$ & $9 \%$ & $3 \%$ \\
\hline 25 & 139 & $24 \%$ & $8 \%$ & $3 \%$ \\
\hline
\end{tabular}

*Author(s) Correspondence:

E-mail: murniati@bundamulia.ac.id 


\begin{tabular}{|c|c|c|c|c|}
\hline 26 & 227 & $28 \%$ & $10 \%$ & $5 \%$ \\
\hline 27 & 224 & $16 \%$ & $5 \%$ & $3 \%$ \\
\hline 28 & 163 & $29 \%$ & $10 \%$ & $3 \%$ \\
\hline 29 & 225 & $19 \%$ & $15 \%$ & $4 \%$ \\
\hline 30 & 198 & $24 \%$ & $11 \%$ & $2 \%$ \\
\hline Total & $\mathbf{4 5 2 4}$ & $\mathbf{7 4 2 \%}$ & $\mathbf{2 5 9 \%}$ & $\mathbf{1 4 5 \%}$ \\
\hline Average & $\mathbf{1 5 0 . 8}$ & $\mathbf{2 4 . 7 \%}$ & $\mathbf{8 . 6 \%}$ & $\mathbf{4 . 8 \%}$ \\
\hline
\end{tabular}

As can be seen in the table above, the average words found in the abstracts published in the reputable journals is 150 words. The highest numbers of words is 247 words and the smallest number is 85 words. It is, therefore, the number of words suggested to be written down in an abstract of retail is 150 words. Regarding the technical vocabularies in business, it can be seen that the average is
$4.8 \%$. The highest is $9 \%$ and the lowest is $2 \%$. The average number shows that it is close to $5 \%$. It is the ideal semi technical vocabularies in accordance to Nation's theory.

Next, Table 2 below shows the technical vocabularies in abstracts which topic is retail. The frequency of each occurrence is also presented in the table.

Table 2. Technical Vocabularies in Retail

\begin{tabular}{|c|c|c|}
\hline No & Words & Frequency \\
\hline 1 & Retail & 75 \\
\hline 2 & Retailer & 21 \\
\hline 3 & Customer & 13 \\
\hline 4 & Retailers & 12 \\
\hline 5 & Retailing & 12 \\
\hline 6 & Customers & 11 \\
\hline 7 & Shoppers & 8 \\
\hline 8 & Sales & 6 \\
\hline 9 & Brand & 6 \\
\hline 10 & Profit & 6 \\
\hline 11 & Bank & 6 \\
\hline 12 & Shopper & 5 \\
\hline 13 & Marketing & 4 \\
\hline 14 & In-store & 4 \\
\hline 15 & Cardholders & 3 \\
\hline 16 & Selling & 3 \\
\hline 17 & Profits & 3 \\
\hline 18 & Companies & 2 \\
\hline 19 & Brands & 2 \\
\hline 20 & Invest & 2 \\
\hline 21 & Banking & 2 \\
\hline 22 & Stock & 2 \\
\hline 23 & Warehouse & 2 \\
\hline 24 & Recession & 2 \\
\hline 25 & Knockoff & 1 \\
\hline 26 & Marketers & 1 \\
\hline 27 & Salesperson & 1 \\
\hline
\end{tabular}

*Author(s) Correspondence:

E-mail: murniati@bundamulia.ac.id 


\begin{tabular}{|l|l|c|}
\hline 28 & Equity & 1 \\
\hline 29 & Competitors & 1 \\
\hline 30 & Buy & 1 \\
\hline 31 & Buyers & 1 \\
\hline 32 & Net & 1 \\
\hline 33 & Sells & 1 \\
\hline 34 & Stocks & 1 \\
\hline 35 & Company & 1 \\
\hline 36 & Warehouses & 1 \\
\hline 37 & Investing & 1 \\
\hline 38 & Share & $\mathbf{2 2 6}$ \\
\hline \multicolumn{2}{|c|}{ Total }
\end{tabular}

As can be seen above, there are the total of 38 words which belong to retail technical vocabularies. As predicted earlier, the highest number of retail of vocabulary is the word "retail". Next, the singular word of "retailer" occurs more often than "retailers". It can be concluded that the research is focusing more on the individual or personal retail company than the retails in groups. Moreover, the singular words of "retail" and "retailer" are still dominating the abstracts. It is interesting that the brand has also become one of the common topics in retail. In general, as we can see, the trends in research are still focusing on the retail in general, the retailer(s) and the customer(s).

\section{Marketing}

The three marketing journals used as the data in these findings are (1) Journal of Business Research, (2) Industrial Marketing Management, and (3) Procedia-Social and Behavioral Sciences. The table below presents both academic and technical vocabularies used in each abstract under the topic of marketing.

Table 3. Percentage of Academic and Technical Vocabularies in Marketing

\begin{tabular}{|c|c|c|c|c|}
\hline Journals & Words & $1-500$ & $501-3000$ & Business \\
\hline 1 & 120 & 26 & 7 & 8 \\
\hline 2 & 108 & 26 & 2 & 3 \\
\hline 3 & 137 & 27 & 10 & 10 \\
\hline 4 & 83 & 29 & 8 & 3 \\
\hline 5 & 140 & 20 & 14 & 4 \\
\hline 6 & 143 & 31 & 10 & 6 \\
\hline 7 & 152 & 24 & 9 & 9 \\
\hline 8 & 97 & 23 & 9 & 5 \\
\hline 9 & 121 & 26 & 12 & 0 \\
\hline 10 & 70 & 27 & 4 & 4 \\
\hline 11 & 172 & 33 & 10 & 8 \\
\hline 12 & 121 & 22 & 10 & 10 \\
\hline 13 & 174 & 34 & 12 & 2 \\
\hline 14 & 166 & 22 & 9 & 10 \\
\hline 15 & 154 & 22 & 14 & 3 \\
\hline 16 & 99 & 33 & 14 & 4 \\
\hline 17 & 178 & 17 & 9 & 1 \\
\hline 18 & 161 & 24 & 6 & 4 \\
\hline
\end{tabular}

*Author(s) Correspondence:

E-mail: murniati@bundamulia.ac.id 


\begin{tabular}{|c|c|c|c|c|}
\hline 19 & 269 & 32 & 9 & 2 \\
\hline 20 & 177 & 32 & 8 & 2 \\
\hline 21 & 87 & 22 & 3 & 4 \\
\hline 22 & 96 & 46 & 4 & 4 \\
\hline 23 & 154 & 25 & 3 & 5 \\
\hline 24 & 129 & 26 & 3 & 7 \\
\hline 25 & 170 & 27 & 3 & 4 \\
\hline 26 & 150 & 22 & 7 & 2 \\
\hline 27 & 113 & 16 & 6 & 1 \\
\hline 28 & 249 & 22 & 6 & 3 \\
\hline 29 & 247 & 35 & 11 & 1 \\
\hline 30 & 132 & 19 & 5 & 0 \\
\hline Total & 4369 & 790 & 237 & 129 \\
\hline Average & $\mathbf{1 4 5 . 6}$ & $\mathbf{2 6 . 3}$ & $\mathbf{7 . 9}$ & $\mathbf{4 . 3}$ \\
\hline
\end{tabular}

As can be seen above, the average of words used in the abstract is 145 words. Not too different from the abstracts which topics are about "retail". The smallest amount of words is 70 words and the highest is 269 . The average of technical vocabularies found is also not too different - that is 4.3 words. It is therefore, suggested that the words used in abstract is about 145 words.

The table below presents the technical words which can be found under the topic of marketing.

Table 4. Business Vocabularies in Marketing

\begin{tabular}{|c|l|c|}
\hline No & \multicolumn{1}{|c|}{ Words } & Frequency \\
\hline 1 & Marketing & 121 \\
\hline 2 & Companies & 8 \\
\hline 3 & Company & 7 \\
\hline 4 & Banking & 1 \\
\hline 5 & Customers & 1 \\
\hline 6 & Customer & 12 \\
\hline 7 & Funds & 1 \\
\hline 8 & Loan & 1 \\
\hline 9 & Profitability & 1 \\
\hline 10 & Marketers & 14 \\
\hline 11 & Sales & 1 \\
\hline 12 & Competitors & 3 \\
\hline 13 & Selling & 1 \\
\hline 14 & Buyers & 6 \\
\hline 15 & entrepreneurial & 1 \\
\hline 16 & entrepreneurs & 3 \\
\hline 17 & business-to-business & 2 \\
\hline 18 & distributors & 1 \\
\hline 19 & bust & 2 \\
\hline 20 & profit & 1 \\
\hline 21 & entrepreneur & 1 \\
\hline 22 & going & 1 \\
\hline 23 & consulting & \\
\hline & & \\
\hline
\end{tabular}

*Author(s) Correspondence:

E-mail: murniati@bundamulia.ac.id 


\begin{tabular}{|c|l|c|}
\hline 24 & retail & 1 \\
\hline 25 & brand & 1 \\
\hline & TOTAL & $\mathbf{1 9 3}$ \\
\hline
\end{tabular}

As can be seen, there are 25 different technical words used in the abstracts which topic is about marketing. The topic word "marketing" is repeated until 121 times. It is interesting that the word "customer" in singular occurs more often than the word "customers" in plural. The trend in marketing research is perhaps about individual customer. The word entrepreneur(s) and entrepreneurial also occur in a quite significant number. This topic might be discussed if the lecturers would like to conduct a research in marketing.

\section{Human Resources}

Human resource, as one of the streams found in Management department in Bunda Mulia University is being discussed as well in this findings. There are three reputable journals in human resource which are used as the data. They are (1) Procedia-Social and Behavioral Sciences, (2) Human Resource Management Review, and (3) European Management Journal. The table below presents the findings.

Table 5. Percentage of Academic and Technical Vocabularies in Human Resources

\begin{tabular}{|c|c|c|c|c|}
\hline Journals & Words & $1-500$ & $501-3000$ & Business \\
\hline 1 & 157 & $33 \%$ & $6 \%$ & $2 \%$ \\
\hline 2 & 95 & $39 \%$ & $4 \%$ & $0 \%$ \\
\hline 3 & 182 & $23 \%$ & $9 \%$ & $2 \%$ \\
\hline 4 & 368 & $30 \%$ & $6 \%$ & $0 \%$ \\
\hline 5 & 264 & $33 \%$ & $6 \%$ & $1 \%$ \\
\hline 6 & 204 & $29 \%$ & $9 \%$ & $0 \%$ \\
\hline 7 & 151 & $35 \%$ & $8 \%$ & $0 \%$ \\
\hline 8 & 140 & $34 \%$ & $4 \%$ & $0 \%$ \\
\hline 9 & 114 & $22 \%$ & $6 \%$ & $1 \%$ \\
\hline 10 & 100 & $22 \%$ & $4 \%$ & $0 \%$ \\
\hline 11 & 110 & $35 \%$ & $9 \%$ & $0 \%$ \\
\hline 12 & 137 & $29 \%$ & $4 \%$ & $0 \%$ \\
\hline 13 & 160 & $29 \%$ & $8 \%$ & $0 \%$ \\
\hline 14 & 153 & $36 \%$ & $2 \%$ & $0 \%$ \\
\hline 15 & 106 & $29 \%$ & $4 \%$ & $0 \%$ \\
\hline 16 & 148 & $24 \%$ & $6 \%$ & $0 \%$ \\
\hline 17 & 183 & $31 \%$ & $8 \%$ & $0 \%$ \\
\hline 18 & 159 & $35 \%$ & $3 \%$ & $0 \%$ \\
\hline 19 & 140 & $23 \%$ & $11 \%$ & $0 \%$ \\
\hline 20 & 58 & $22 \%$ & $12 \%$ & $0 \%$ \\
\hline 21 & 129 & $38 \%$ & $12 \%$ & $0 \%$ \\
\hline 22 & 242 & $33 \%$ & $8 \%$ & $0 \%$ \\
\hline 23 & 127 & $25 \%$ & $12 \%$ & $1 \%$ \\
\hline 24 & 109 & $30 \%$ & $12 \%$ & $0 \%$ \\
\hline 25 & 153 & $33 \%$ & $9 \%$ & $5 \%$ \\
\hline 26 & 133 & $42 \%$ & $11 \%$ & $0 \%$ \\
\hline 27 & 151 & $35 \%$ & $3 \%$ & $0 \%$ \\
\hline
\end{tabular}

*Author(s) Correspondence:

E-mail: murniati@bundamulia.ac.id 


\begin{tabular}{|c|c|c|c|c|}
\hline 28 & 234 & $35 \%$ & $7 \%$ & $0 \%$ \\
\hline 29 & 135 & $39 \%$ & $4 \%$ & $0 \%$ \\
\hline 30 & 127 & $21 \%$ & $8 \%$ & $0 \%$ \\
\hline Total & $\mathbf{4 6 6 9}$ & $\mathbf{9 2 4 \%}$ & $\mathbf{2 1 5 \%}$ & $\mathbf{1 2 \%}$ \\
\hline Average & $\mathbf{1 5 5 . 6}$ & $\mathbf{3 0 . 8 \%}$ & $\mathbf{7 . 2 \%}$ & $\mathbf{0 . 4 \%}$ \\
\hline
\end{tabular}

The table shows that the average number of words in the abstracts is 155.6. Comparing to the previous words used in abstracts in other topics, this result shows a similar number. The technical vocabularies, unfortunately, show a very low percentage. It covers only $0.4 \%$ of the overall words used in the abstract. It is quite different from the average of the required semi technical vocabularies which should reach at least $5 \%$ of the total words used. In short, the results indicate that the lecturers who are interested in publishing their research regarding human resource - cannot send their articles to business journals, especially those three journals which data are used in this research.

The following table shows the technical vocabularies of human resource found in all of the abstracts.

Table 6. Technical Vocabularies in Human Resources

\begin{tabular}{|c|l|c|}
\hline No & \multicolumn{1}{|c|}{ Words } & Frequency \\
\hline 1 & Brand & 7 \\
\hline 2 & Entrepreneurial & 4 \\
\hline 3 & Funds & 3 \\
\hline 4 & Bank & 3 \\
\hline 5 & Company & 3 \\
\hline 6 & Outsourced & 2 \\
\hline 7 & Companies & 2 \\
\hline 8 & Shareholder & 2 \\
\hline 9 & Outsource & 1 \\
\hline 10 & Outsourcing & 1 \\
\hline 11 & Marketing & 1 \\
\hline 12 & Share & 1 \\
\hline & Total & $\mathbf{3 0}$ \\
\hline
\end{tabular}

Unlike the previous topics, there are only 12 technical vocabularies found in human resource topic. The total words are also limited, they are only 30 words. In addition, it covers $0.4 \%$ of the overall vocabularies. The highest occurrence is also about the word "brand". Considering that this word also occurs in another topic, it can be said that the word "brand" is considered as semi technical vocabularies. These findings show that the human resource cannot be analyzed by using technical vocabularies in business.

\section{Finance}

There are three finance journals which abstracts are discussed in these findings: (1) Research in International Business and Finance, (2) Procedia Economics and Finance, and (3) Procedia-Social and Behavioral Sciences. The results can be seen in the table below.

*Author(s) Correspondence:

E-mail: murniati@bundamulia.ac.id 
Table 7. Percentage of Academic and Technical Vocabularies in Finance

\begin{tabular}{|c|c|c|c|c|}
\hline No & Words & $1-500$ & $501-3000$ & Business \\
\hline 1 & 110 & $25 \%$ & $2 \%$ & $4 \%$ \\
\hline 2 & 132 & $27 \%$ & $8 \%$ & $0 \%$ \\
\hline 3 & 150 & $20 \%$ & $12 \%$ & $1 \%$ \\
\hline 4 & 195 & $19 \%$ & $6 \%$ & $3 \%$ \\
\hline 5 & 138 & $20 \%$ & $9 \%$ & $0 \%$ \\
\hline 6 & 270 & $27 \%$ & $7 \%$ & $0 \%$ \\
\hline 7 & 101 & $17 \%$ & $7 \%$ & $0 \%$ \\
\hline 8 & 138 & $21 \%$ & $5 \%$ & $3 \%$ \\
\hline 9 & 152 & $21 \%$ & $8 \%$ & $4 \%$ \\
\hline 10 & 225 & $23 \%$ & $8 \%$ & $3 \%$ \\
\hline 11 & 226 & $20 \%$ & $11 \%$ & $1 \%$ \\
\hline 12 & 133 & $23 \%$ & $14 \%$ & $0 \%$ \\
\hline 13 & 174 & $22 \%$ & $7 \%$ & $1 \%$ \\
\hline 14 & 207 & $16 \%$ & $4 \%$ & $0 \%$ \\
\hline 15 & 246 & $19 \%$ & $7 \%$ & $4 \%$ \\
\hline 16 & 212 & $14 \%$ & $4 \%$ & $4 \%$ \\
\hline 17 & 150 & $22 \%$ & $11 \%$ & $4 \%$ \\
\hline 18 & 116 & $34 \%$ & $8 \%$ & $0 \%$ \\
\hline 19 & 145 & $19 \%$ & $8 \%$ & $1 \%$ \\
\hline 20 & 155 & $26 \%$ & $6 \%$ & $0 \%$ \\
\hline 21 & 227 & $23 \%$ & $6 \%$ & $0 \%$ \\
\hline 22 & 276 & $22 \%$ & $8 \%$ & $3 \%$ \\
\hline 23 & 82 & $23 \%$ & $7 \%$ & $0 \%$ \\
\hline 24 & 155 & $21 \%$ & $6 \%$ & $3 \%$ \\
\hline 25 & 121 & $18 \%$ & $6 \%$ & $0 \%$ \\
\hline 26 & 98 & $28 \%$ & $10 \%$ & $0 \%$ \\
\hline 27 & 96 & $10 \%$ & $4 \%$ & $4 \%$ \\
\hline 28 & 163 & $17 \%$ & $12 \%$ & $8 \%$ \\
\hline 29 & 194 & $14 \%$ & $8 \%$ & $5 \%$ \\
\hline 30 & 157 & $22 \%$ & $4 \%$ & $4 \%$ \\
\hline Total & 4944 & $633 \%$ & $223 \%$ & $60 \%$ \\
\hline Average & 164.8 & $21.1 \%$ & $7.4 \%$ & $2 \%$ \\
\hline
\end{tabular}

The results show that the average words used in abstract is slightly higher than the abstracts in other topic. It reaches 164.8 words. The range is between 82 words to the highest 276 words. The technical vocabularies are also slightly lower than the average; it reaches only $2 \%$ of the overall words used. It can indicate that the topic finance does not really belong to business technical vocabulary list. However, it cannot be said that finance does not belong to business; it is simply because the technical vocabularies are really specific.

The table below shows all of the technical vocabularies found in all of the abstracts, together with their occurrences.

*Author(s) Correspondence:

E-mail: murniati@bundamulia.ac.id 
Table 8. Technical Vocabularies in Finance

\begin{tabular}{|c|c|c|}
\hline No & Words & Frequency \\
\hline 1 & Assets & 11 \\
\hline 2 & Companies & 8 \\
\hline 3 & Stock & 7 \\
\hline 4 & Investors & 7 \\
\hline 5 & Profit & 7 \\
\hline 6 & Bank & 7 \\
\hline 7 & Banking & 5 \\
\hline 8 & Bonds & 5 \\
\hline 9 & Banks & 4 \\
\hline 10 & Loans & 4 \\
\hline 11 & Cash & 4 \\
\hline 12 & Entrepreneurs & 3 \\
\hline 13 & Earnings & 3 \\
\hline 14 & Net & 3 \\
\hline 15 & Lenders & 3 \\
\hline 16 & Shares & 3 \\
\hline 17 & Company & 2 \\
\hline 18 & Funds & 2 \\
\hline 19 & Fund & 2 \\
\hline 20 & Short-term & 2 \\
\hline 21 & Borrower & 2 \\
\hline 22 & Fixed-income & 1 \\
\hline 23 & Entrepreneurship & 1 \\
\hline 24 & Equity & 1 \\
\hline 25 & Invest & 1 \\
\hline 26 & Yield & 1 \\
\hline 27 & Bond & 1 \\
\hline 28 & Bondholders & 1 \\
\hline 29 & Estate & 1 \\
\hline 30 & Revenue & 1 \\
\hline 31 & Loan & 1 \\
\hline 32 & Customers & 1 \\
\hline 33 & Going & 1 \\
\hline 34 & Leasing & 1 \\
\hline 35 & Rental & 1 \\
\hline 36 & Sales & 1 \\
\hline 37 & Revenues & 1 \\
\hline 38 & Accountants & 1 \\
\hline 39 & Back-office & 1 \\
\hline 40 & Diversified & 1 \\
\hline 41 & Invoices & 1 \\
\hline 42 & Marketing & 1 \\
\hline 43 & Oracle & 1 \\
\hline 44 & Outsourcing & 1 \\
\hline 45 & Borrowers & 1 \\
\hline
\end{tabular}

*Author(s) Correspondence:

E-mail: murniati@bundamulia.ac.id 


\begin{tabular}{|c|c|c|}
\hline 46 & Profitability & 1 \\
\hline 47 & Volatility & 1 \\
\hline 48 & Yahoo & 1 \\
\hline & Total & 121 \\
\hline
\end{tabular}

It can be seen from the table above that the total number of technical vocabularies found in the abstracts is 121. Even though the number is significant, since the percentage only reaches $2 \%$ of the overall, it can be said that it is not sufficient enough. The highest frequency is the word "asset". It is interesting that the technical vocabulary such as "yahoo" is considered as the technical vocabularies in finance. The research in finance is closely related to bank, banks, and banking.

\section{Strategic Management}

The findings below is taken from three reputable journals, they are (1) Procedia-Social and Behavioral Sciences, (2) European Journal of Operational Research, and (3) Journal of Business Research. The total words, academic, and technical vocabularies found in the abstract can be seen in the table below.

Table 9. Percentage of Academic and Technical Vocabularies in Strategic Management

\begin{tabular}{|c|c|c|c|c|}
\hline Journals & Words & $1-500$ & $501-3000$ & Business \\
\hline 1 & 176 & $22 \%$ & $8 \%$ & $0 \%$ \\
\hline 2 & 219 & $34 \%$ & $8 \%$ & $0 \%$ \\
\hline 3 & 100 & $30 \%$ & $15 \%$ & $2 \%$ \\
\hline 4 & 150 & $29 \%$ & $10 \%$ & $1 \%$ \\
\hline 5 & 113 & $29 \%$ & $4 \%$ & $0 \%$ \\
\hline 6 & 330 & $21 \%$ & $7 \%$ & $12 \%$ \\
\hline 7 & 110 & $18 \%$ & $16 \%$ & $0 \%$ \\
\hline 8 & 94 & $30 \%$ & $14 \%$ & $0 \%$ \\
\hline 9 & 153 & $27 \%$ & $14 \%$ & $1 \%$ \\
\hline 10 & 247 & $19 \%$ & $4 \%$ & $0 \%$ \\
\hline 11 & 212 & $30 \%$ & $6 \%$ & $0 \%$ \\
\hline 12 & 235 & $27 \%$ & $9 \%$ & $0 \%$ \\
\hline 13 & 205 & $25 \%$ & $17 \%$ & $0 \%$ \\
\hline 14 & 193 & $15 \%$ & $9 \%$ & $2 \%$ \\
\hline 15 & 292 & $19 \%$ & $8 \%$ & $0 \%$ \\
\hline 16 & 146 & $23 \%$ & $6 \%$ & $4 \%$ \\
\hline 17 & 247 & $13 \%$ & $6 \%$ & $3 \%$ \\
\hline 18 & 165 & $28 \%$ & $16 \%$ & $0 \%$ \\
\hline 19 & 249 & $23 \%$ & $12 \%$ & $2 \%$ \\
\hline 20 & 187 & $33 \%$ & $15 \%$ & $0 \%$ \\
\hline 21 & 112 & $32 \%$ & $13 \%$ & $5 \%$ \\
\hline 22 & 138 & $15 \%$ & $14 \%$ & $2 \%$ \\
\hline 23 & 148 & $24 \%$ & $14 \%$ & $0 \%$ \\
\hline 24 & 140 & $21 \%$ & $16 \%$ & $0 \%$ \\
\hline 25 & 147 & $38 \%$ & $10 \%$ & $0 \%$ \\
\hline 26 & 143 & $17 \%$ & $7 \%$ & $4 \%$ \\
\hline 27 & 134 & $18 \%$ & $10 \%$ & $0 \%$ \\
\hline
\end{tabular}

*Author(s) Correspondence:

E-mail: murniati@bundamulia.ac.id 


\begin{tabular}{|c|c|c|c|c|}
\hline 28 & 139 & $29 \%$ & $7 \%$ & $2 \%$ \\
\hline 29 & 146 & $27 \%$ & $11 \%$ & $2 \%$ \\
\hline 30 & 198 & $26 \%$ & $7 \%$ & $2 \%$ \\
\hline Total & $\mathbf{5 2 6 8}$ & $\mathbf{7 4 2 \%}$ & $\mathbf{3 1 3 \%}$ & $\mathbf{4 4 \%}$ \\
\hline Average & $\mathbf{1 7 5 . 6}$ & $\mathbf{2 4 . 7 \%}$ & $\mathbf{1 0 . 4 \%}$ & $\mathbf{1 . 5 \%}$ \\
\hline
\end{tabular}

Comparing with the previous topic, the average words used in the abstracts in the strategic management is 175.6 words. The range is between 94 and the highest is 330 .
The technical vocabulary is also not too many, it covers only $1.5 \%$ of the overall texts.

The technical vocabularies in strategic management in detail can be seen in the table below.

Table 10. Technical Vocabularies in Strategic Management

\begin{tabular}{|c|c|c|}
\hline No & Words & Frequency \\
\hline 1 & Entrepreneurship & 4 \\
\hline 2 & Companies & 2 \\
\hline 3 & Strategists & 1 \\
\hline 4 & Brand & 28 \\
\hline 5 & Marketing & 4 \\
\hline 6 & Brands & 4 \\
\hline 7 & Company & 2 \\
\hline 8 & Customer & 4 \\
\hline 9 & Equity & 2 \\
\hline 10 & Assets & 8 \\
\hline 11 & Branded & 1 \\
\hline 12 & Invest & 1 \\
\hline 13 & Sales & 1 \\
\hline 14 & Profitable & 2 \\
\hline 15 & Customers & 6 \\
\hline 16 & Profit & 6 \\
\hline 17 & Business-to-business & 1 \\
\hline 18 & Buy & 1 \\
\hline 19 & Buying & 1 \\
\hline 20 & Sell & 1 \\
\hline 21 & Selling & 1 \\
\hline 22 & Portfolio & 2 \\
\hline 23 & Asset & 1 \\
\hline 24 & Profitability & 2 \\
\hline 25 & Valuation & 1 \\
\hline 26 & Retailer & 8 \\
\hline 27 & Short-term & 2 \\
\hline 28 & Sold & 1 \\
\hline 29 & Shareholder & 2 \\
\hline 30 & Competitor & 1 \\
\hline 31 & Shareholders & 1 \\
\hline 32 & Entrepreneurial & 2 \\
\hline
\end{tabular}

*Author(s) Correspondence:

E-mail: murniati@bundamulia.ac.id 


\begin{tabular}{|c|l|c|}
\hline 33 & Entrepreneur & 1 \\
\hline 34 & Entrepreneurs & 1 \\
\hline \multicolumn{2}{|c|}{ TOTAL } & $\mathbf{1 0 6}$ \\
\hline
\end{tabular}

The table shows that there 106 technical words or $1.5 \%$ of the overall words in relation to strategic management found in the abstracts published in reputable journals. It might happen due to the fact that the topics are interrelated with other topic. As can be seen above, highest occurrence is the word "brand". It is, therefore, suggested that the topic is related to the brand. In addition, it could be related too other high occurrences, such as retail and assets.

\section{CONCLUSION}

In conclusion, the overall results of all of the topics regarding their occurrences of both academic and technical vocabularies can be seen below.

Table 11. Overall Results

\begin{tabular}{|l|c|c|c|c|}
\hline \multicolumn{1}{|c|}{ Topic } & Words & $\mathbf{1 - 5 0 0}$ & $\mathbf{5 0 1 - 3 0 0 0}$ & Business \\
\hline Retail & 150.8 & $24.7 \%$ & $8.6 \%$ & $4.8 \%$ \\
\hline Marketing & 145.6 & $26.3 \%$ & $7.9 \%$ & $4.3 \%$ \\
\hline Human Resource & 155.6 & $30.8 \%$ & $7.2 \%$ & $0.4 \%$ \\
\hline Finance & 164.8 & $21.1 \%$ & $7.4 \%$ & $2 \%$ \\
\hline Strategic Management & 175.6 & $24.7 \%$ & $10.4 \%$ & $1.5 \%$ \\
\hline
\end{tabular}

Regarding the total words found in all of the abstracts in one topic and the academic vocabularies, the results are not really different from one topic to another. Regarding the technical vocabularies, the results are quite different. The retail and marketing topics have got similar results which are different from the results of human resource, finance, and strategic management topics. Those different results might happen due to the academic vocabularies list itself. A word can be put in the academic vocabulary list if it occurs more than 10 times in all areas. Since the vocabularies, for example in finance, are really specific, those words might not appear in the list. As a result, the percentage is a bit lower than others.

Those results also indicate that more corpus programs are needed to analyze technical vocabularies which are really specific. Ideally, each topic has its own corpus database, in order that more research on those specific topics can be conducted for a valid result. For example, the finance topic has a finance corpus data based; the finance topic should not be included under the business topics.

The program which is used to analyze the technical vocabularies in this research, wordandphrase.info, is quite good, considering that other programs cannot really accommodate the needs of analyzing the academic and technical vocabularies. However, not all of the topics can be analyzed accurately by using this program, such as the technical vocabularies for finance topics.

Last but not least, it can be seen that the abstracts should be easy to understand since the first $1-500$ words percentage is higher than the percentage of $500-3000$ academic words used in the abstracts. It is suggested that the Management Department lecturers who are going to write the abstract are following this pattern. The range of 1-500 words should be about $20-30 \%$, and the range of $500-3000$ words should be about $7-10 \%$.

As for suggestions, the results of this research can actually be applied in other areas in terms that other lecturers who want to conduct research and send them to reputable journals can follow the steps in this research.

*Author(s) Correspondence:

E-mail: murniati@bundamulia.ac.id 
The steps can basically be divided into two big steps. The first one is as follows:

1) Open www.sciencedirect.com and login

2) Search the keywords

3) Choose the highest three journals. This step shows which journal is appropriate for the topic chosen

4) Limit the search to the newest year

5) Click on the article. If it is open access, it can be downloaded. If not, other links must be open, such as from Proquest

6) Click on the title, search from scholar. Google.com, then click "quote" The reference is then copy pasted

After all of the data is available, it is time to do the second step. They are as follows.

1) Open www.worandphrase.info and login

2) Choose "analyze the texts

3) Upload the data

4) Choose the "academic list"

5) The total words used are available, together with the academic and technical words

6) Click on the technical vocabularies. Several areas of interest are available

7) The analysis is put in a table for further analysis

\section{REFERENCES}

Coxhead, A. (2000). A new academic word list. TESOL quarterly, 34(2), 213-238.

Crystal, D. (2003). English as a global language. Cambridge: Cambridge University Press. Print.

Hunston, S. (2002). Corpora in applied linguistics. Cambridge: Cambridge University Press.

Kachru, B.B. (1989). Teaching world Englishes. Indian Journal of Applied Linguistics, 15(1),85-95

Martín-Monje, E., Elorza, I., \& Riaza, B. G. (Eds.). (2016). Technology-enhanced Language Learning for Specialized Domains: Practical Applications and Mobility (Vol. 163). Routledge.

Nation, I. S. (2001). Learning vocabulary in another language. Cambridge: Cambridge University Press.

Richards, J. C., \& Schmidt, R. W. (2013). Longman dictionary of language teaching and applied linguistics. Abingdon: Routledge

*Author(s) Correspondence:

E-mail: murniati@bundamulia.ac.id 